\title{
Surgical treatment of dental and skeletal Class III malocclusion
}

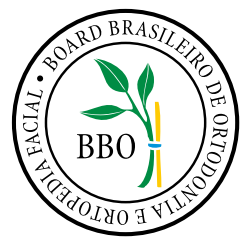

Ione Helena Vieira Portella Brunharo ${ }^{1}$

Orthodontic preparation for surgical treatment of skeletal Class III malocclusion involves joint planning with an oral and maxillofacial surgeon to address the functional and esthetic needs of the patient. In order to allow surgical manipulation of the jaws in the preoperative phase, the need to achieve a negative overjet through incisor decompensation often leads the orthodontist to extract the upper first premolars. This report illustrates an orthodontic preparation case where due to specific factors inherent in the patient's psychological makeup retroclination of the upper incisors and proclination of the mandibular incisors was achieved without removing any teeth. This case was presented to the Brazilian Board of Orthodontics and Facial Orthopedics (BBO) in partial fulfillment of the requirements for obtaining the BBO Diploma.

Keywords: Class III malocclusion. Surgery. Orthosurgical preparation.

O preparo ortodôntico para tratamento cirúrgico do padrão esquelético de Classe III envolve o planejamento em conjunto com o cirurgião bucomaxilofacial, com o objetivo de solucionar as necessidades funcionais e estéticas do paciente. A fim de permitir a manipulação cirúrgica das bases ósseas, a obtenção de overjet negativo por meio da descompensação dos incisivos, na fase pré-cirúrgica, leva, com frequência, o ortodontista a optar pela exodontia dos primeiros pré-molares superiores. O presente relato ilustra um caso de preparo ortodôntico no qual, devido a fatores específicos inerentes à questão psicológica da paciente, a retroinclinação dos incisivos superiores e vestibularização dos incisivos inferiores foi realizada sem a remoção de elementos dentários. Esse caso foi apresentado à diretoria do Board Brasileiro de Ortodontia e Ortopedia Facial (BBO) como parte dos requisitos para a obtenção do título de Diplomado pelo BBO.

Palavras-chave: Má oclusão de Classe III. Tratamento cirúrgico. Preparo orto-cirúrgico.

\section{INTRODUCTION}

Caucasian female patient, aged 17 years and 7 months, reported dissatisfaction with her facial and dental esthetics after undergoing orthodontic treatment to camouflage her negative overjet. The patient's substantially compromised lower face made her feel a deep dissatisfaction with her face. The interview revealed good overall health and a family history of mandibular prognathism, a trait inherited from the paternal side.

${ }^{1}$ Visiting Professor, Department of Orthodontics, Rio de Janeiro State University, $\mathrm{PhD}$ in Orthodontics, Rio de Janeiro State University. Diplomate of the Brazilian Board of Facial Orthopedics (BBO).

How to cite this article: Brunharo IHVP. Surgical treatment of dental and skeletal Class III malocclusion. Dental Press J Orthod. 2013 Jan-Feb; 18(1):143-9.

\section{DIAGNOSIS}

Facial examination disclosed a brachycephalic facial pattern $\left(\mathrm{GoGnSN}=28^{\circ}, \mathrm{FMA}=18^{\circ}\right)$, despite an increased chin height. The mandible showed a slight asymmetry to the right, concave profile, acute nasolabial angle and obtuse mentolabial angle. Smile analysis showed a low smile line with a little upper incisor exposure, and well developed buccal corridors (Fig 1). Intraoral evaluation indicated low risk of caries and healthy periodontal tissues.

\footnotetext{
" The author reports no commercial, proprietary or financial interest in the products or companies described in this article.

» Patients displayed in this article previously approved the use of their facial and in traoral photographs.
}

Contact address: Ione Helena Vieira Portella Brunharo Rua Almirante Tamandaré, 59 - Rio de Janeiro/RJ - Brazil - CEP: 22.210-060 Email: ioneportella@yahoo.com.br 
The dental arches in occlusion exhibited a Class III molar and canine relationship. All permanent teeth were present, except for the third molars. There was also an overbite in edge-to-edge relationship, and $0 \mathrm{~mm}$ overjet due to a prior orthodontic compensation. Teeth in the lower dental arch showed a pronounced lingual inclination (Figs 1 and 2.)
In examining the panoramic radiograph, permanent teeth displayed good root parallelism, and the presence of intraosseous third molars (Figure 3). Cephalometric analysis revealed a skeletal Class III pattern $\left(\mathrm{ANB}=-8^{\circ}\right)$, brachycephalic growth pattern $\left(\mathrm{SN}-\mathrm{GoGn}=28^{\circ}\right)$, and lingual inclination of the lower incisors (IMPA $=69^{\circ}$, $\left.1-\mathrm{NB}=4^{\circ}\right)($ Fig 4 , Table 1.)
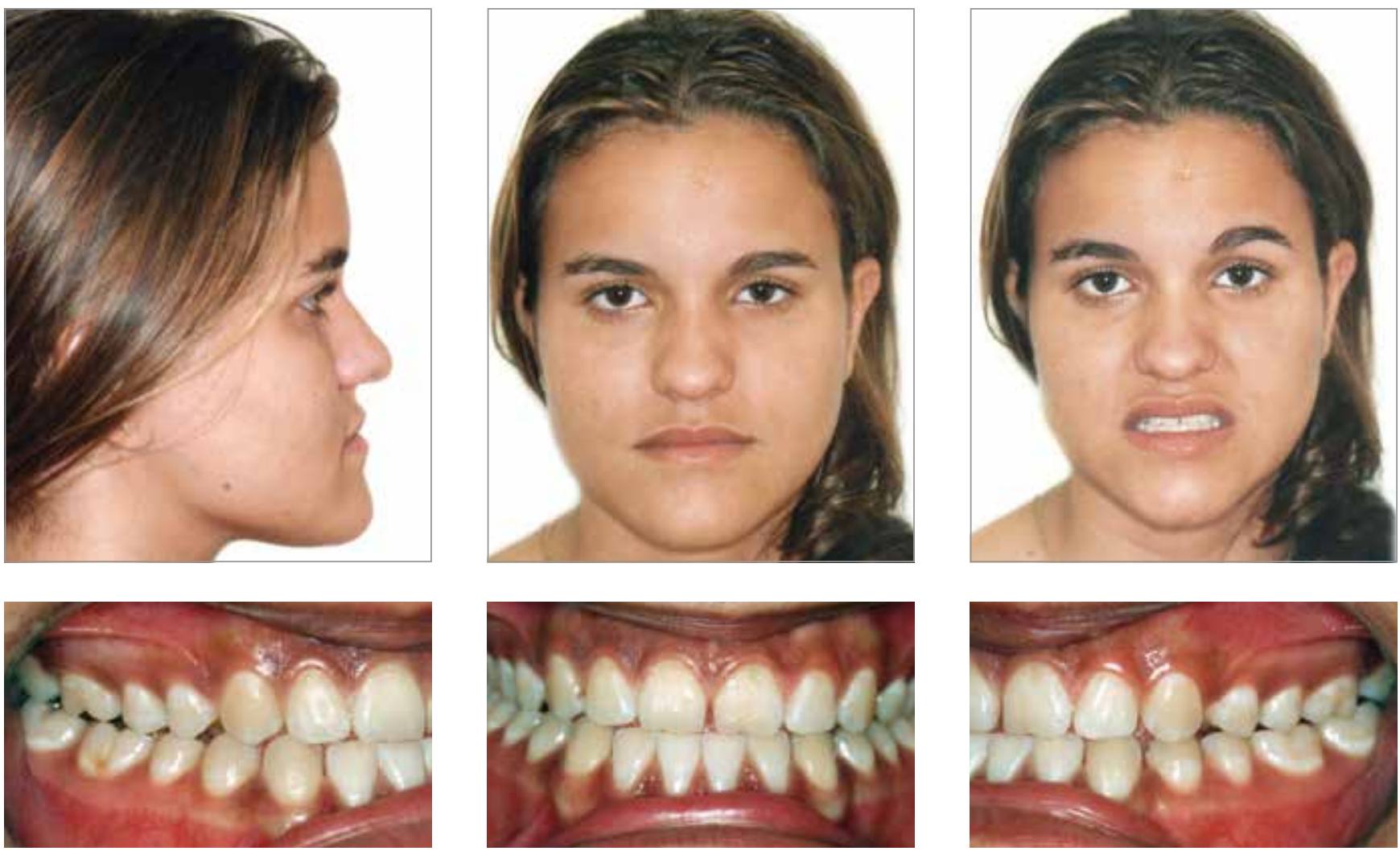

Figure 1 - Initial facial and intraoral photographs
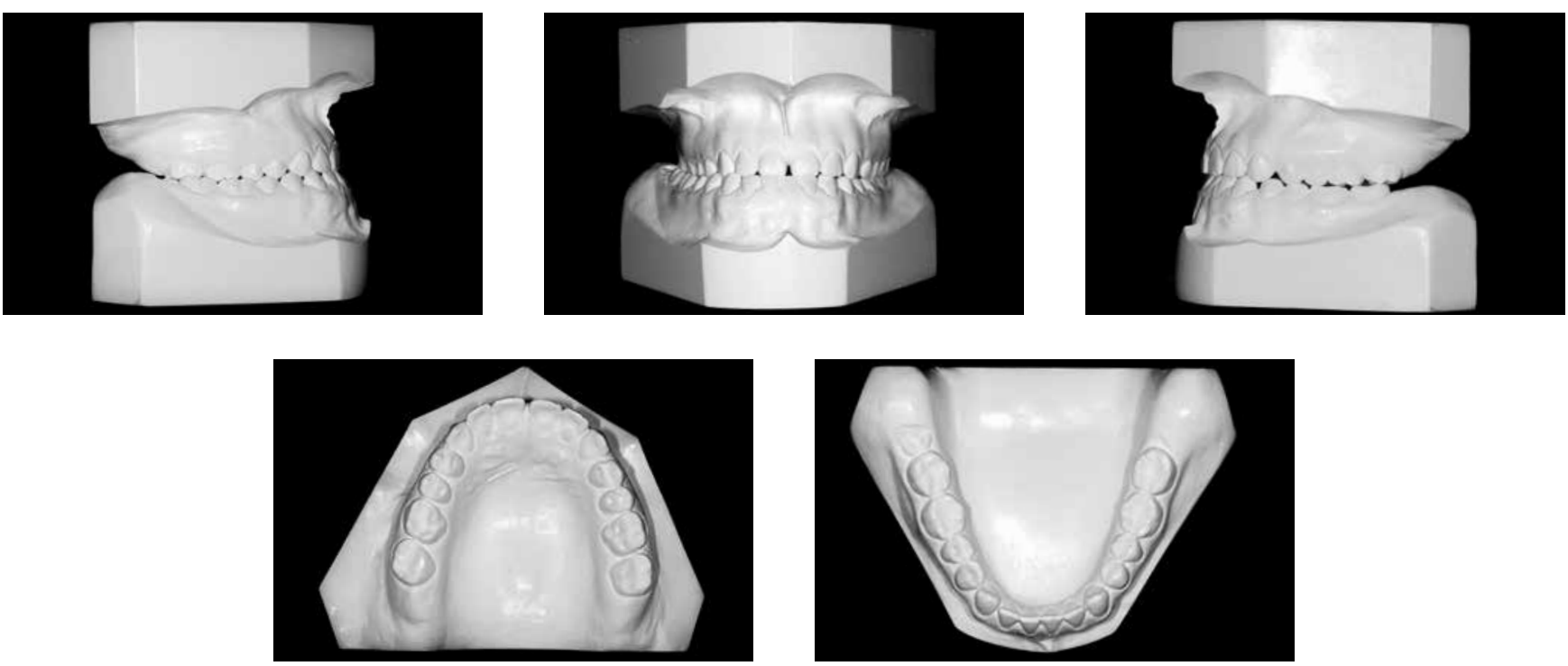

Figure 2 - Initial models. 


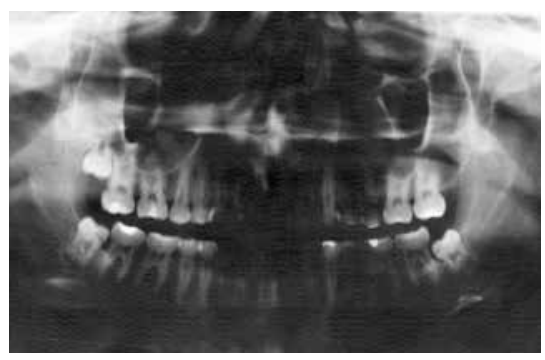

Figure 3 - Initial panoramic radiograph.

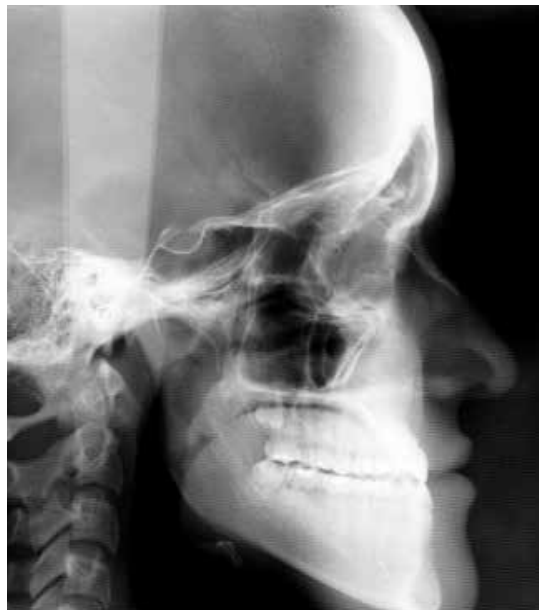

Figure 4 - Initial cephalometric radiograph and tracing

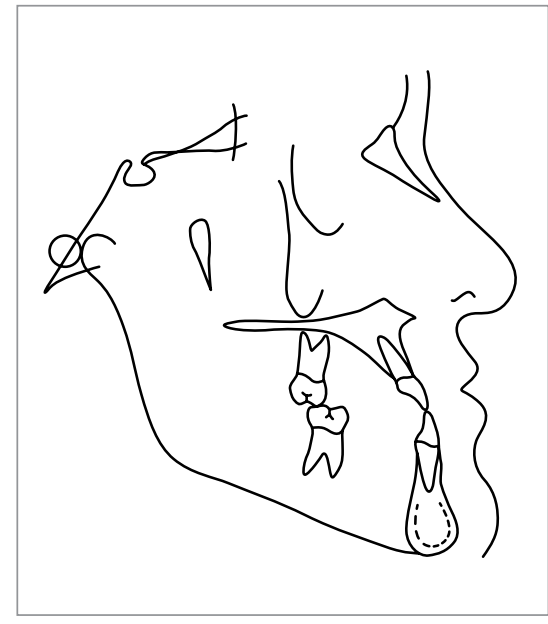

\section{TREATMENT GOALS}

The patient's facial esthetics was substantially compromised given the size of the mandible, which made her too shy to smile and interact socially. Cephalometric analysis revealed a good anteroposterior maxillary relationship, with the mandible positioned anteriorly to the cranial base.

The therapy of choice to correct the skeletal discrepancy was orthosurgical treatment through dental decompensation to help the patient recover her selfesteem. After discussing the case with the surgeon, the treatment plan was submitted to the patient and two options were proposed. The first involved extraction of the first premolars and retraction of the upper incisors, utilizing the space obtained previously. In this case the orthodontist could more easily reposition the maxillary anterior teeth while a negative overjet could be easily achieved orthodontically. However, it was explained to the patient that she would have to endure a period of compromised esthetics, just the time required for space closure. She was also made aware of the need for combined surgery. ${ }^{1,2}$

The second option would be to perform dental decompensation by utilizing any small spaces present in the upper jaw, and straightening up the teeth in the lower arch. This option would prepare the arches more rapidly for the surgical procedure, which would only involve mandibular setback., ${ }^{2,3}$

After clarifying these points to the patient, both the professionals and the patient chose an orthodontic preparation without extraction of the first premolars.

\section{TREATMENT PLANNING}

Standard edgewise metal brackets with $0.022 \mathrm{x}$ 0.028-in slot was the technique/appliance employed to perform the orthodontic treatment. Initially, both dental arches were aligned and leveled for decompensation of the teeth in the jaw bones. Alignment was performed by coordinating 0.014 to 0.020 -in steel archwires.

Thereafter, a steel $0.017 \times 0.025$-in archwire was placed in the upper arch with pronounced buccal torques in the incisors, combining Class II elastic mechanics with the support of crimpable hooks placed in the interproximal space between canines and lateral incisors, an in the mandibular arch a 0.020-in archwire with omegas was placed away from the tubes. The elastic mechanics delivered an intermaxillary force of about 180 grams. Thus, it was possible to reposition the maxillary incisors lingually while migrating the lower posterior teeth mesially, and protruding the lower incisors to increase negative overjet.

Stabilizing $0.019 \times 0.025$-in archwires were placed in order to achieve optimal dental torques with tightly tied omega loops, and preserve dental arch perimeter. Coordination impressions were taken to verify an optimal preoperative engagement. Once this ideal engagement was observed the patient was referred to the assistant surgeon, and interproximal hooks were placed (Figs 5, 6, 7.)

Mandibular setback surgery was carried out using the vertical technique. In the postoperative period it became necessary to use a lower 0.020-in archwire, implement elastic mechanics to correct the midline and establish the occlusion (Figs 8 and 9). ${ }^{4}$ 

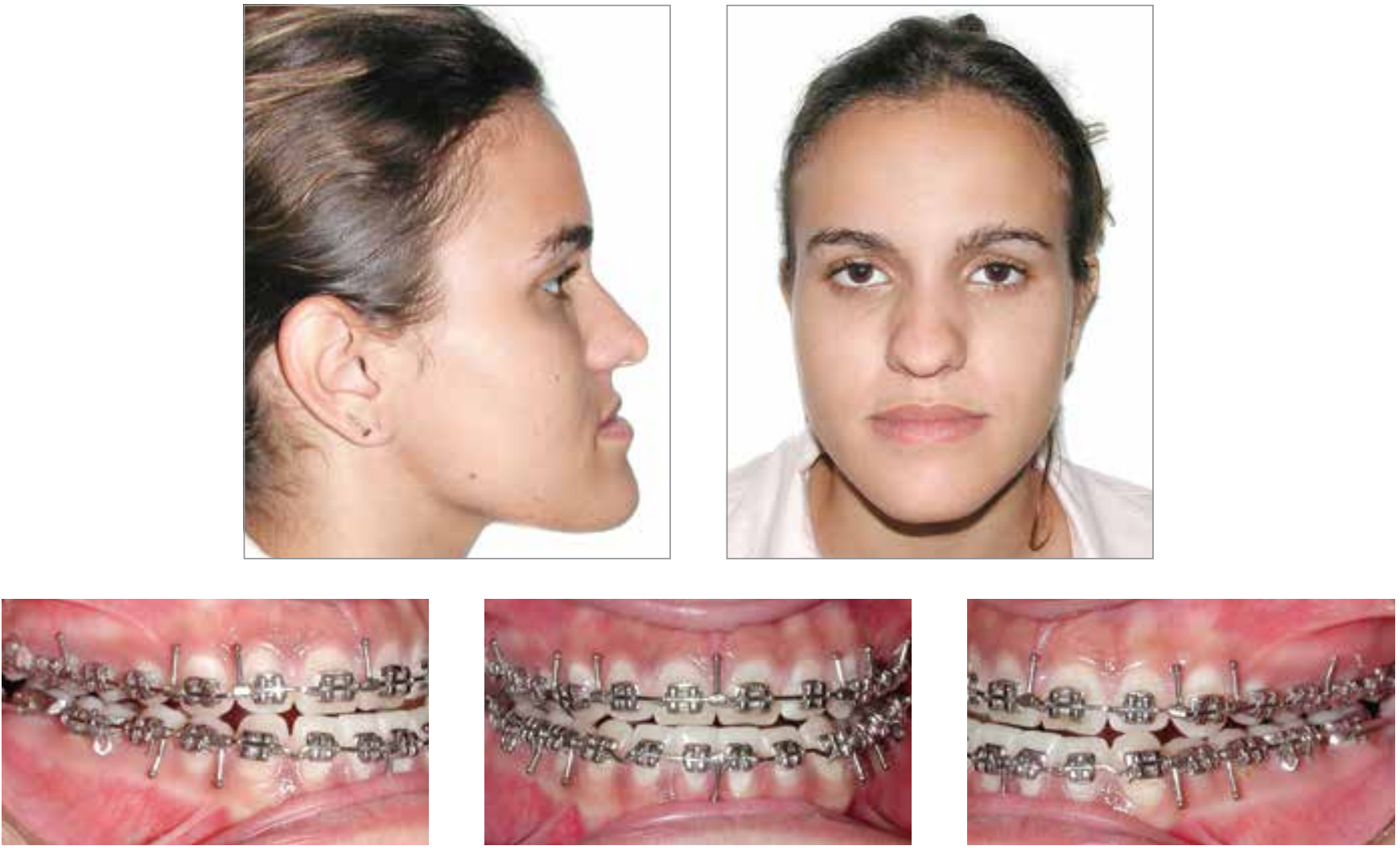

Figure 5 - Preoperative facial and intraoral photographs.
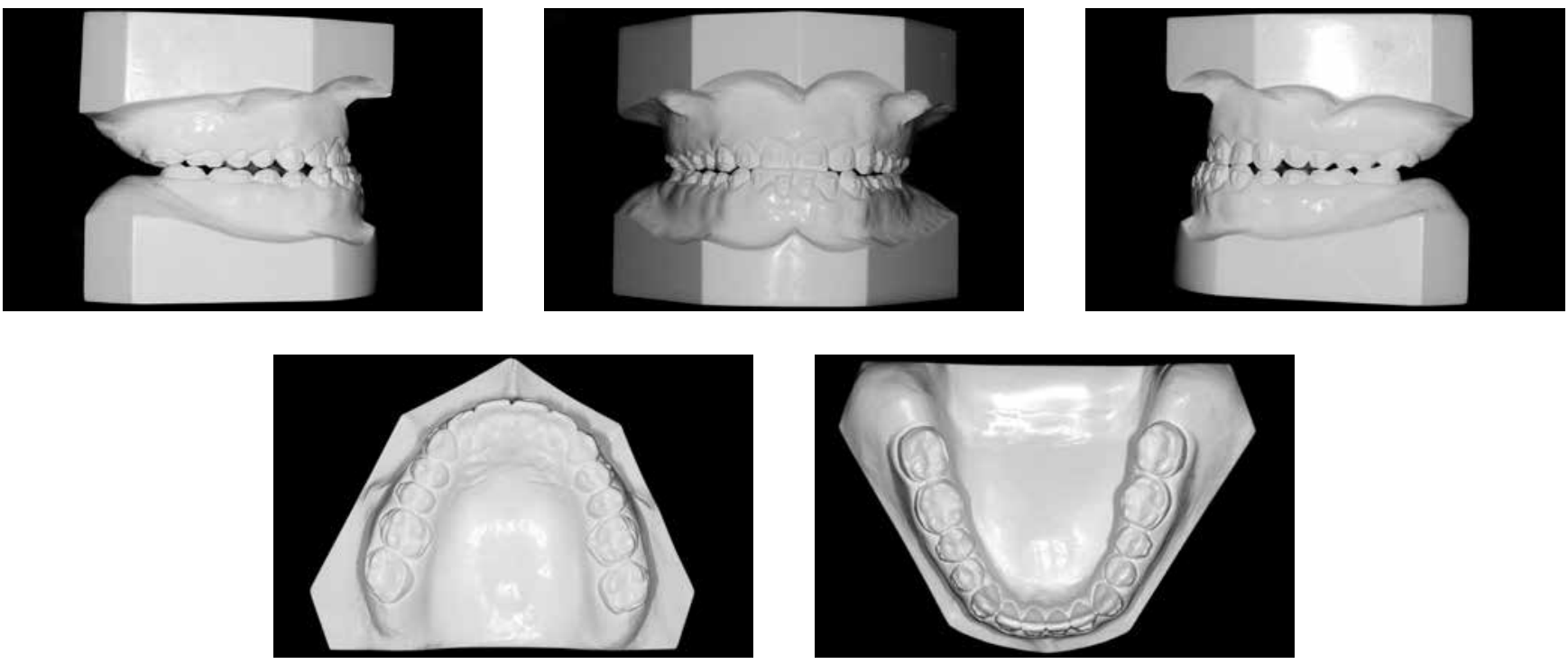

Figure 6 - Preoperative casts 

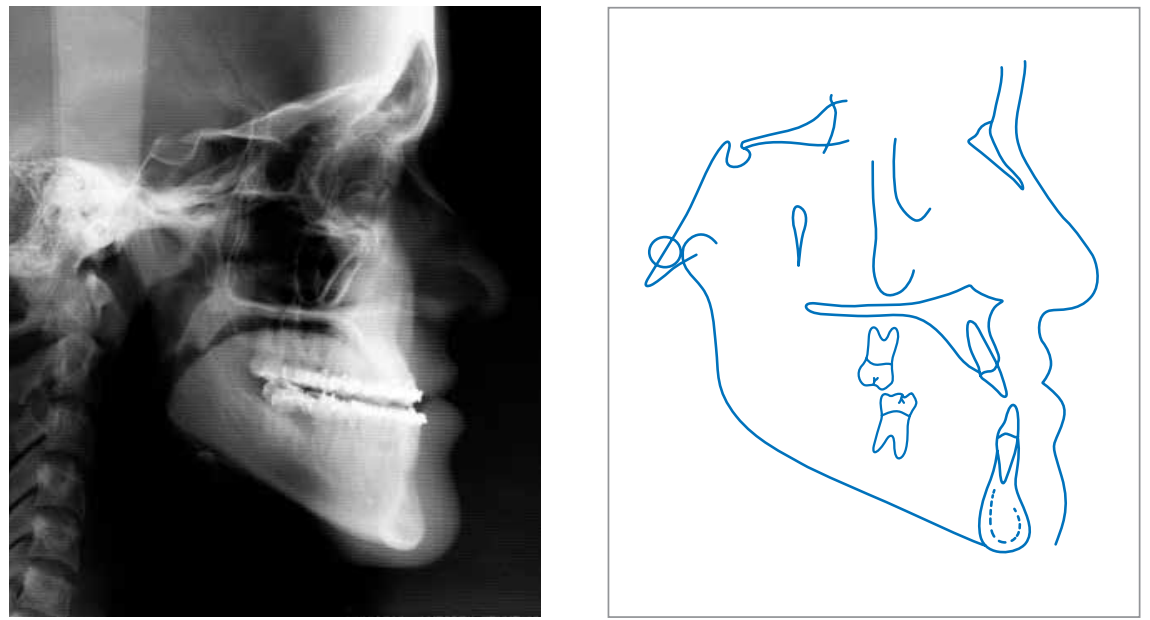

Figure 7 - Preoperative cephalometric radiograph and tracing

Retention consisted of a wraparound retainer in the upper arch and in the lower arch a 0.020-in lingual bar bonded from canine to canine, tooth by tooth.

\section{RESULTS}

After removal of the appliance the final records showed that the position of the maxilla was maintained and the anteroposterior position of the mandible was re- duced $\left(\mathrm{SNA}=80^{\circ}, \mathrm{SNB}=81^{\circ}\right)$. The mandible exhibited a clockwise rotation relative to the anterior base of the skull $\left(\mathrm{GoGnSN}=35^{\circ}, \mathrm{FMA}=27^{\circ}\right)$ (Table 1) (Figs 8-12).

The final occlusion showed a good relationship between the dental arches with favorable molar relationship, canines in Class I, and normal overbite and overjet. Functional balance and healthy periodontal tissues were achieved (Figs 8-12).
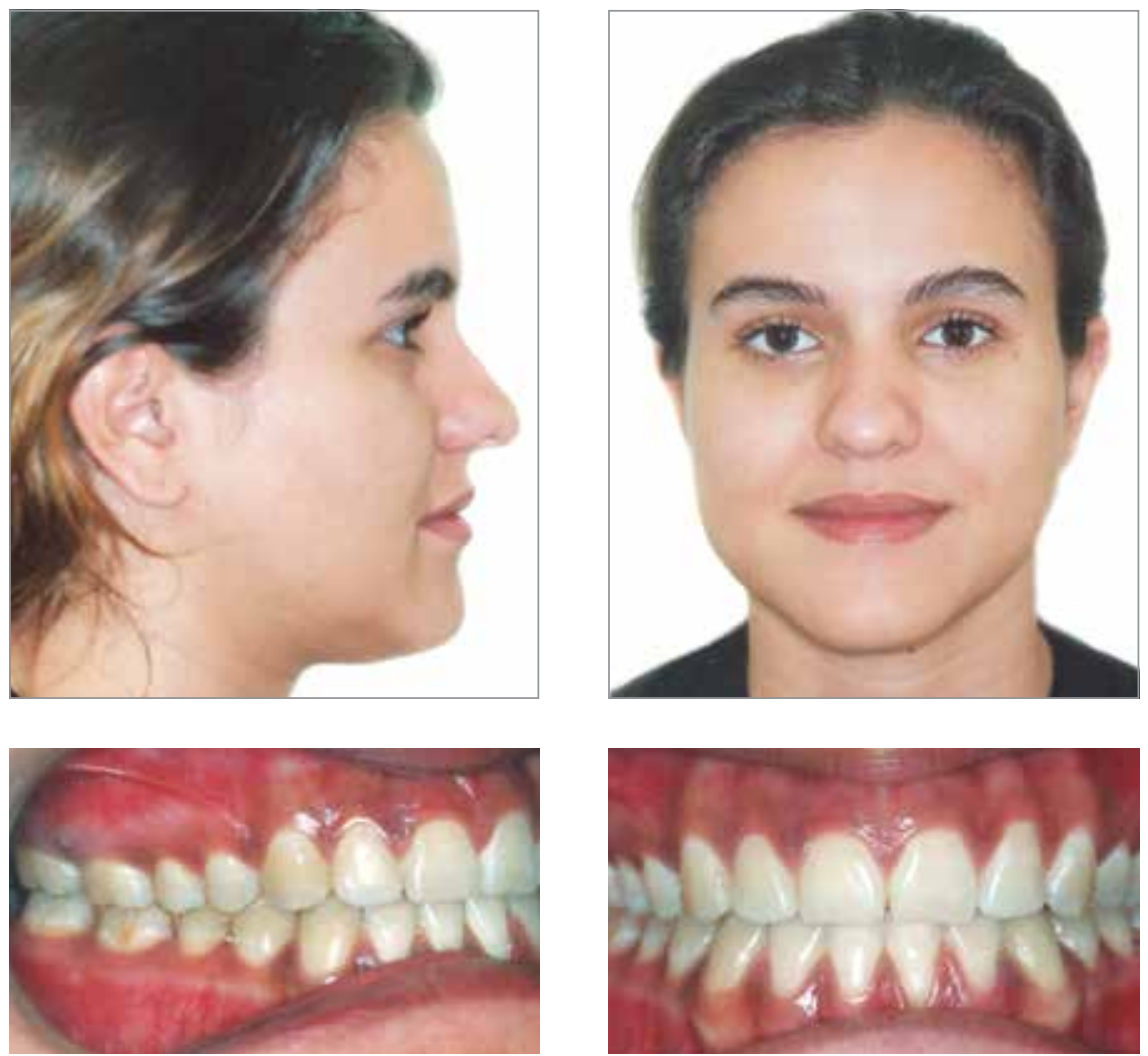
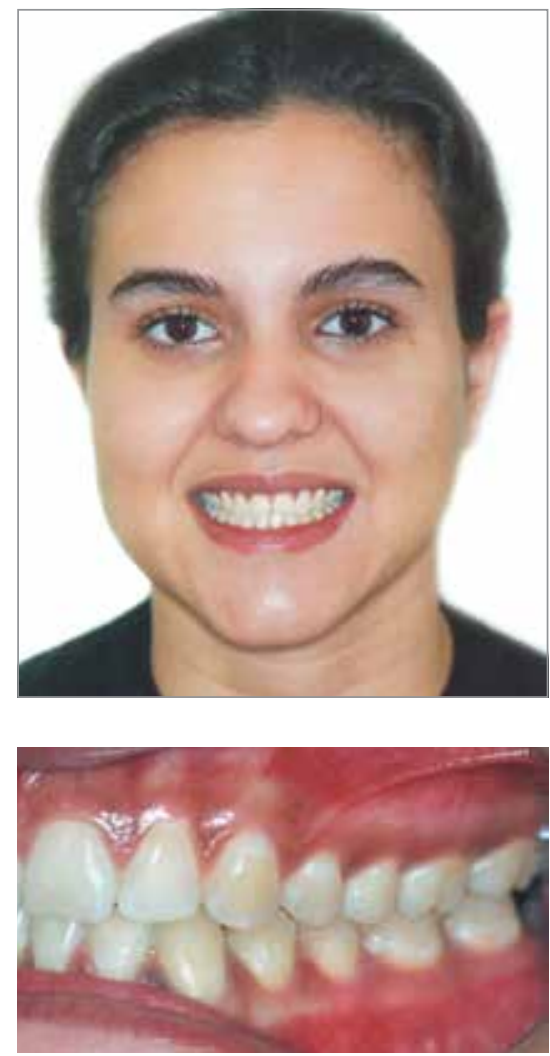

Figure 8 - Final facial and intraoral photographs. 

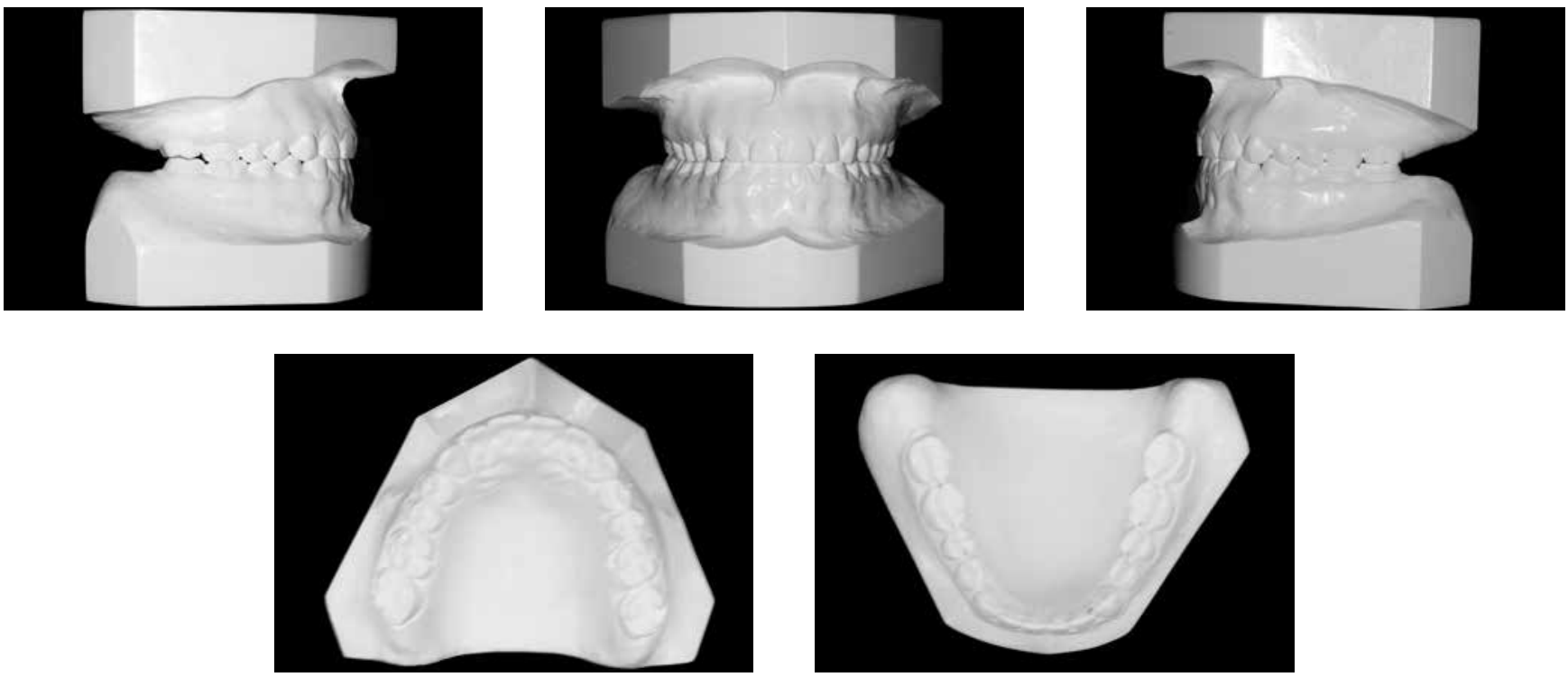

Figure 9 - Final casts.

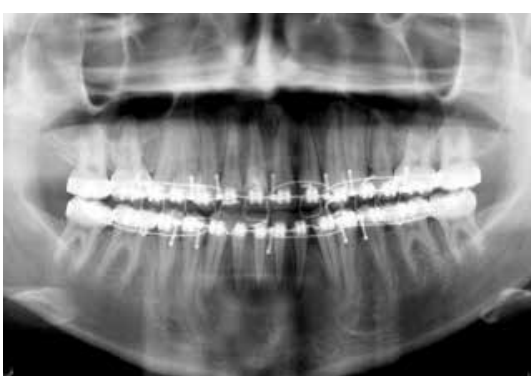

Figure 10 - Final panoramic radiograph.
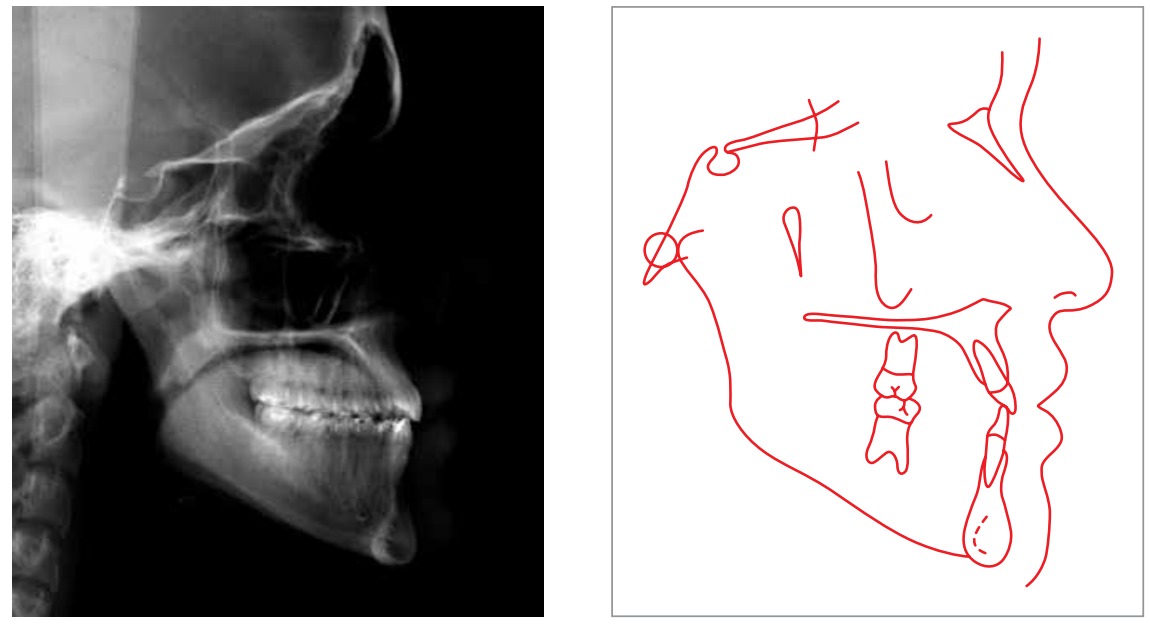

Figure 11 - Final cephalometric radiograph and tracing
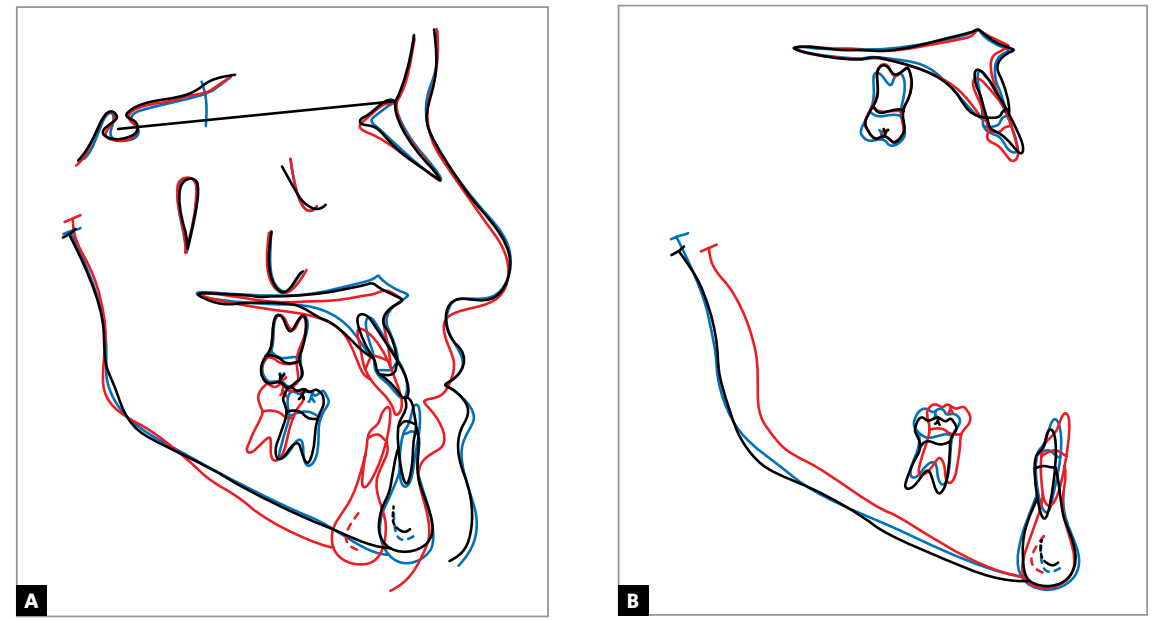

Figure 12 - Total (A) and partial (B) cephalometric superimpositions of initial (black), pre-operative (blue) and final (red) tracings. 
Table 1 - Summary of cephalometric measurements.

\begin{tabular}{|c|c|c|c|c|c|c|c|}
\hline & \multicolumn{2}{|c|}{ MEASURES } & Normal & $\mathrm{A}$ & $A_{1}$ & B & Diff. $A / B$ \\
\hline \multirow{8}{*}{ Skeletal pattern } & SNA & (Steiner) & $82^{\circ}$ & $80^{\circ}$ & $81.5^{\circ}$ & $80^{\circ}$ & 0 \\
\hline & SNB & (Steiner) & $80^{\circ}$ & $88^{\circ}$ & $88^{\circ}$ & $81^{\circ}$ & 7 \\
\hline & ANB & (Steiner) & $2^{\circ}$ & $-8^{\circ}$ & $-6.5^{\circ}$ & $-1^{\circ}$ & 7 \\
\hline & Convexity angle & (Downs) & $0^{\circ}$ & $-17^{\circ}$ & $-15^{\circ}$ & $-6^{\circ}$ & 11 \\
\hline & $Y$ axis & (Downs) & $59^{\circ}$ & $50^{\circ}$ & $55^{\circ}$ & $56^{\circ}$ & 6 \\
\hline & Facial angle & (Downs) & $87^{\circ}$ & $97^{\circ}$ & $94^{\circ}$ & $92^{\circ}$ & 5 \\
\hline & SN-GoGn & (Steiner) & $32^{\circ}$ & $28^{\circ}$ & $30.5^{\circ}$ & $35^{\circ}$ & 7 \\
\hline & FMA & (Tweed) & $25^{\circ}$ & $18^{\circ}$ & $24^{\circ}$ & $27^{\circ}$ & 9 \\
\hline \multirow{7}{*}{ Dental pattern } & IMPA & (Tweed) & $90^{\circ}$ & $69^{\circ}$ & $72^{\circ}$ & $78^{\circ}$ & 9 \\
\hline & 1.NA (degrees) & (Steiner) & $22^{\circ}$ & $34^{\circ}$ & $25.5^{\circ}$ & $30^{\circ}$ & 4 \\
\hline & 1-NA (mm) & (Steiner) & $4 \mathrm{~mm}$ & $7 \mathrm{~mm}$ & $5.5 \mathrm{~mm}$ & $6 \mathrm{~mm}$ & 1 \\
\hline & I.NB (degrees) & (Steiner) & $25^{\circ}$ & $4^{\circ}$ & $9^{\circ}$ & $15^{\circ}$ & 11 \\
\hline & 1-NB (mm) & (Steiner) & $4 \mathrm{~mm}$ & $-1.5 \mathrm{~mm}$ & $0 \mathrm{~mm}$ & $3 \mathrm{~mm}$ & 4.5 \\
\hline & $\frac{1}{1}$-Interincisal Angle & (Downs) & $130^{\circ}$ & $150^{\circ}$ & $146^{\circ}$ & $135^{\circ}$ & 15 \\
\hline & I-APo (mm) & (Ricketts) & $1 \mathrm{~mm}$ & $2 \mathrm{~mm}$ & $3 \mathrm{~mm}$ & $2 \mathrm{~mm}$ & 0 \\
\hline \multirow{2}{*}{ Profile } & Upper Lip - S Line & (Steiner) & $0 \mathrm{~mm}$ & $-4 \mathrm{~mm}$ & $-5.5 \mathrm{~mm}$ & $-1.5 \mathrm{~mm}$ & 2.5 \\
\hline & Lower Lip - S Line & (Steiner) & $0 \mathrm{~mm}$ & $-2 \mathrm{~mm}$ & $-2.5 \mathrm{~mm}$ & $-1 \mathrm{~mm}$ & 1 \\
\hline
\end{tabular}

\section{CONCLUSIONS}

Orthosurgical treatment of skeletal Class III malocclusion enjoys wide acceptance among patients who seek an orthodontist to have their condition addressed. The use of orthodontic camouflage to solve this problem requires that the professional evaluate the patient's face, and if facial esthetics is found to be an issue, orthodontic treatment alone is unlikely to succeed. ${ }^{5}$

In this clinical case report the treatment results met the planned expectations. Issues regarding surgical sta- bility remain unresolved since the patient did not accept the initial proposal to have her first premolars extracted during orthosurgical preparation. Thus, although the facial esthetic outcome was satisfactory, obtaining a preoperative negative overjet proved rather challenging. For this reason the case requires continued follow-up during the retention phase. ${ }^{4}$

The patient and her legal guardians were very pleased with the final result, which considerably improved her self-esteem.
1. Phillips C, Proffit WR. Phycosocial aspects of dentofacial deformities and its treatment. In: Proffit WR, Fields HW, Sarver DM, editors. Contemporary treatment of dentofacial deformity. St. Louis: Mosby; 2003. Chap. 3.

2. Proffit WR, Phillips C, Sarver DM. Tratamento cirúrgico e ortodôntico combinados. In: Proffit WR, Fields HW, Sarver DM, editors. Ortodontia contemporânea. Rio de Janeiro: Mosby; 2007. Cap. 8.

3. Proffit WR, Phillips C, Sarver DM. Tratamento cirúrgico e ortodôntico combinados. In: Proffit WR, Fields HW, Sarver DM, editors. Ortodontia contemporânea. Rio de Janeiro: Mosby; 2007. Cap. 7
4. Blaker GH III, White Jr RP. Mandibular surgery. In: Proffit WR, Fields HW, Sarver DM, editors. Contemporary treatment of dentofacial deformity. St. Louis: Mosby; 2003. Chap. 10

5. Kiyak HA, West RA, Hohl T, McNeill RW. The psychological impact of orthognatic surgery: a 9-month follow-up. Am J Orthod. 1982:81(5):404-12. 